\title{
Corporate Governance Framework for Shariah Compliant Corporation
}

\author{
Hartinie Abd Aziz ${ }^{1, *}$ Zuhairah Ariff Abd Ghadas ${ }^{2}$ \\ ${ }^{1}$ Universiti Sultan Zainal Abidin \\ ${ }^{2}$ Universiti Sultan Zainal Abidin \\ ${ }^{*}$ Corresponding author: Faculty of Law and International Relations, Universiti Sultan Zainal Abidin
}

\begin{abstract}
Corporate governance emphasise on the moral and ethical dimensions of managing a company's business. The word corporate governance refers to a system of control of corporation and systems of accountability of those in control. The High Level Finance Committee Report 1999, defines corporate governance as a process of directing a business and the affairs of the company towards enhancing business prosperity and corporate accountability with the ultimate objective of realising long-term shareholder values, whilst taking into account the interest of other stakeholders". Under Shariah, corporate governance main purpose is not only to work for the benefit of the shareholders and the stakeholders but also to acknowledge the duty of mankind to God and to the rest of the people living in the community. This paper analyse the corporate governance legal framework from both conventional and Shariah perspective to identify what would be the appropriate corporate governance model for Shariah compliant corporation.
\end{abstract}

Keywords: Corporate Governance, Shariah Compliant Corporation

\section{INTRODUCTION}

Presently, the rapid development of the Islamic finance industry requires the need to have a Shariah governance framework. The tools used to meet the unique needs of the Islamic financial industry are the Shariah governance guidelines. At present, the current Shariah governance guidelines are issued by BNM, IFSB, and AAOIFI.

A Shariah corporate structure is not similar with the conventional structure. The legal framework for a Shariah Corporation should cover all the requirements such as the legality of business entities, the attributes of the companies and the shariah corporate governance.

\subsection{IFSB Shariah Governance Guidelines}

The Islamic Financial Services Board (IFSB), which is based in Kuala Lumpur, was officially inaugurated on 3rd November 2002 and began operation on 10th March 2003. The role of IFSB is to serve as an international standardsetting body of regulatory and supervisory agency to ensure the soundness and stability of the Islamic financial services industry, not only in banking but in capital market and insurance. In completing this mission, IFSB is developing a new standards or revising an existing international standards to be consistent with Shariah principles as well as suggesting the standards for implementation which therefore lead to fosters the development of a prudent and transparent Islamic financial services industry.
As of December 2017, there are 185 members of the IFSB comprising 75 regulatory and supervisory authorities, eight international inter-governmental organisations, and 102 market players (financial institutions, professional firms, industry associations and stock exchanges) operating in 57 jurisdictions. Malaysia, the host country of the IFSB, has enacted a law known as the Islamic Financial Services Board Act 2002, which gives the IFSB the immunities and privileges that are usually granted to international organisations and diplomatic missions [1].

IFSB defines a Shariah governance system as a set of institutional and organisational arrangements through which an Islamic financial institution ensures that there is effective independent oversight of Shariah compliance of each of the following structures and processes[2]:

a) Issuance of relevant Shariah pronouncement or resolution. This refers to a juristic opinion on any matter pertaining to Shariah issues in Islamic finance given by the appropriately mandated Shariah board.

b) Dissemination of information on such Shariah pronouncement or resolutions to the operative personnel of the IFIs who monitor the day-to-day compliance with the Shariah resolutions vis-à-vis every level of operations and each transaction. However, this task would normally be done by the internal Shariah compliance department.

c) An internal Shariah compliance review or audit reports that if there is any incident of non-compliance, it should be recorded and addressed and rectified. In regard to this, IFSB-3 
sets out that Shariah resolution issued by the Shariah boards should be strictly adhered to.

d) An annual Shariah compliance review or audit for verifying that internal Shariah compliance review or audit has been appropriately carried out and its findings have been duly noted by the Shariah boards.

The Shariah governance system is to complement the existing governance, control, and compliance functions within IFIS, as shown in the table below.

Table 1.1: $\quad$ Comparison of shariah governance system in IFI with existing conventional system.

\begin{tabular}{|l|l|l|}
\hline FUNCTIONS & \multicolumn{1}{|c|}{$\begin{array}{c}\text { TYPICAL FINANCIAL } \\
\text { INSTITUTION }\end{array}$} & \multicolumn{1}{|c|}{ ADDITIONS IN IIFS } \\
\hline Governance & - Board of directors & - Shar' ah board \\
\hline Control & $\begin{array}{l}\text { - Internal auditor } \\
\text { - External auditor }\end{array}$ & $\begin{array}{l}\text { - ISRU } \\
\text { - External Shari ah review }\end{array}$ \\
\hline Compliance & $\begin{array}{l}\text { - Regulatory and financial } \\
\text { compliance officers, unit or } \\
\text { department }\end{array}$ & - ISCU \\
\hline
\end{tabular}

Based on the table above, from the governance aspect, IFIs should have a Shariah board in addition to board of directors. Pertaining to control mechanism, IFIs should have both internal and external Shariah review units in addition to conventional internal and external auditors. In terms of compliance, IFIs should comply with Shariah in addition to compliance with the conventional regulatory and financial requirements. However, in reality, the detailed scope may vary from one jurisdiction to another, depending on the types of structures adopted by the IFIs as permitted by the relevant authorities[2].

IFSB further provides guiding principles in the following five sections: the general approach to Shariah governance system, competency, independency, confidentiality, and consistency.

\subsection{AAOIFI Shariah Governance Standard}

Basically, there are seven standards under the governance standards for Islamic Financial Institution which issued by AAOIFI: (1) ShariahSupervisory Board: Appointment, Composition and Report, (2) ShariahReview, (3) Internal ShariahReview, (4) Audit \& Governance Committee for Islamic Financial Institutions, (5) Independence of ShariahSupervisory Boards, (6) Statement on Governance Principles for Islamic Financial Institutions, (7) Corporate Social Responsibility Conduct and Disclosure for Islamic Financial Institutions.

\subsection{Shariah Governance Framework of Bank Negara Malaysia (BNM) 2012}

The objectives of Shariah governance framework (SGF 2012) issued by Bank Negara Malaysia (BNM) are to set out the expectations of the bank on an IFI's Shariah governance structures, processes, and arrangements. The purposes are to (1) ensure that all its operations and business activities are in accordance with Shariah; (2) provide a comprehensive guidance to the board, Shariah committee, and management of the IFI in discharging its duties in matters relating to Shariah; and (3) outline the functions relating to Shariah review, Shariah audit, Shariah risk management and Shariah research. Generally, the framework is discussed in six sections related to the general requirement, oversight, accountability and responsibility, independence, competency, confidentiality and Shariah compliance, and research function.

According to the general requirements of the Shariah governance framework, the essential key functions of the key organs in Shariah governance framework are the board, Shariah committee, management and Shariah compliance, and research functions. According to the BNM Shariah governance framework, IFIs are responsible for establishing a sound and robust Shariah governance framework with an emphasis placed on the roles of key functionalities in ensuring effective implementation of the Shariah governance framework. In regard to overseeing, accountability and responsibility, IFIs shall set out the accountability and responsibility of every key functionary involved in the implementation of the Shariah governance framework. To safeguard the independence of the Shariah committee, IFIS shall ensure a sound Shariah decision-making and emphasis on the role of the board of directors in recognising the independence of the Shariah committee.[3]

\section{MALAYSIAN IFI MODEL}

In Malaysia, the existing Shariah governance framework is established for the Islamic Financial institution. To ensure that the overall Islamic financial system operates in accordance with Shariah principles, Bank Negara Malaysia requires the establishment of a two-tier Shariah governance infrastructure comprising two vital components: a centralised Shariah advisory council at the BNM and an internal Shariah Committee formed in each IFI[4].

According to (Section 51)[5], it provides that, "The Shariah Advisory Council on Islamic Finance shall be established by the Central Bank of Malaysia, and the Council shall be the authority for the ascertainment of Islamic law for the purposes of Islamic financial business. The council is given authority to determine its own procedures in carrying out their duties under the Act".

The Section 52 of the same act provides the functions of the Shariah Advisory Council as to ascertain the Islamic law on any financial matter and issue a ruling upon reference made to it in accordance with Part VII of the Act, to advise the Bank 
on any Shariah issue relating to Islamic financial business, the activities or transactions of the Bank and to provide advice to any Islamic financial institution or any other person as may be provided under any written law in force in Malaysia; and such other functions as may be determined by the Bank.

The members of the Shariah Advisory Council shall be selected from among those who are qualified in Shariah or who have knowledge or experience in Shariah and banking, finance, law, or other related disciplines; and the appointment shall be made by the Yang di-Pertuan Agong on the advice of the Minister of Finance and after consultation with the Central Bank (Section 53)[5].

In Section 55[5], it mentioned about the needs for the the Bank to consult the Shariah Advisory Council on any matter relating to Islamic financial business as well as in conducting its businesses and affairs to be in conformity with the Shariah, as determined by the Shariah Advisory Council, under this Act or any other written legislation. In executing its duties and responsibilities, the Shariah Advisory Council shall examine and endorse the validity of application of Shariah in Islamic financial products, which are presented by Islamic financial institutions under the supervision of the Central Bank of Malaysia.

Section 55(2) additionally states that any Islamic financial institution may request a ruling or seek guidance from the Shariah Advisory Council on its Islamic financial business activities in order to ensure that it does not include any elements that are incompatible with Shariah.

In section 56 (1), it provides that, the presiding judge or arbitrator are required to refer to the published rulings of the Shariah Advisory Council or to request for advice from the Council in order to determine any issue concerning a Shariah matter before them.

It should be noted that, every request for advice or ruling of the Shariah Advisory Council under this Act or any other law shall be submitted to the secretariat which is established under section 54. In the event of conflict between the ruling issued by a Shariah committee of an Islamic financial institutions and the ruling issued by the Shariah Advisory Council, the ruling of the Shariah Advisory Council shall prevail and be applicable.

Apart from the CBA 2009, the rule relating to Shariah governance is provided under Section 30 until section 36 of IFSA 2013 whereby these provisions highlighted the matters regarding to the appointment and qualification of the Shariah Committees members in Islamic financial institution. The Central Bank of Malaysia Act 2009 only provides the general requirement for financial institution to have a Shariah committee but this current provision provides a more specific requirement under section 30 of IFSA 2013 which requires an institution to apply directly to the Central Bank for the establishment of Shariah Committee. This will enable the Central Bank to have direct information as to the members of the Shariah Committee in an Islamic financial institution, which at the same time, to ensure a proper supervision towards the activities conducted[6].

Under the new IFSA, a clear standard of requirement pertaining to the appointment of such committee is highlighted under Section 31, which is to be read together with section 29 (2) (a) which provides, only those who is really fit and qualified may be appointed as the Shariah Committee members. Therefore, the members of the Shariah committee in every financial institution must be chaired by those who met the requirements as stated by the Central Bank. The existence of such a clause would be fundamental in ensuring that the products and services introduced by the Islamic financial institution comply with the Shariah principles via the supervision of competent members.

Section 32 of IFSA 2013 contributes to the significance of Shariah committees in every institution through the introduction of the Shariah governance, which not only sets out the duties of the Shariah committees in the institution but also blends into the structure of the company itself. By extending the powers of Shariah governance into certain aspects in a company such as matters involving the board of directors and internal Shariah compliance, we can understand that Shariah governance would be one of the integral parts in an institution up to the point that Shariah comittee may no longer be treated as a minor part or division of a company, what more against the idea of abandoning such governance rules.

The introduction of under section 33 and 34 of IFSA, on the other hand, enables the Central Bank to continuously be updated by the institution of its Shariah Committee members. In order to maintain its aim of ensuring that only those who really qualifies entitled to be the members, the provision set out the clause relating to the cessation of the members including situations which would disqualifies from becoming Shariah committee members.

Due to the precise rules and features of the Shariah committee members, therefore, it is mandatory for management in charge of the company to provide a detailed information to the Shariah committee in exercising its task and duties as provided under section 35 of IFSA 2013. However, under this Act, it did not specify the type and degree of information required. Therefore, it is reasonable to presume that, the Shariah Committee has the authority to request any information that would assist them in carrying out their duties.

In addition, section 36 denotes the legislative trust placed in the Shariah Committee to preserve any type of information, including confidential information, as long as that information is not shared with others. While keeping their obligation of confidentiality, Shariah committees are also protected by the qualified privilege, which protects them from being sued by an Islamic financial institution if it can be demonstrated that their duties were carried out in good faith.

The provision clauses as to the Shariah governance is one of the major features being introduced under the IFSA 2013 to 
strengthen the Shariah Committee's authority and functions, and to ensure that the any activities of Islamic financial institutions are compliant with Shariah and therefore, it will provides a strong and robust Shariah governance structure in Malaysia's Islamic financial industry.

The Shariah governance framework of an IFI shall, at the minimum, comprise the following:

a) The Shariah compliance parts of the IFI's overall activities are overseen by the board. The board of directors is ultimately responsible for establishing an IFI's Shariah governance framework. The board is expected to understand the Shariah non-compliance risks associated with Islamic finance business, as well as the concerns surrounding such risks and their potential consequences for the institution, when establishing the Shariah governance framework.

b) A Shariah Committee comprised of qualified members capable of deliberating Islamic finance matters and making sound Shariah rulings. In this context, every IFI must form a Shariah Committee, with the majority of members having adequate Shariah qualifications and expertise.

c) Effective management responsibilities in providing adequate resources and capable manpower support to every function involved in the implementation of Shariah governance, in order to ensure that the execution of business operations is in accordance with the Shariah;

d) An internal Shariah review that is conducted on a continuous basis, which is a review of processes and deliverables, as well as determining that such processes and outcomes satisfy the needs of the Shariah;

e) A regular Shariah audit, at least on an annual basis, verifying that the IFI's key functions and business operations comply with Shariah;

f)

A Shariah risk management process to identify all possible Shariah non-compliance risks and, where appropriate, remedial measures that need to be taken to reduce the risk;

g) An internal Shariah research team to conduct research on Shariah; and

h) Issuance and dissemination of Shariah decisions to the relevant stakeholders. The framework requires that the Shariah governance framework of an Islamic financial institution comprises few key functionaries beginning from the boards who have a very ultimate responsibility in overseeing (1) the Shariah-complying aspects of the Islamic financial institution's overall operation, (2) it's Shariah committee, (3) the effectiveness of the management responsible in providing adequate resources in the implementation of Shariah governance, (4) its internal Shariah reviewer, (5) the regular Shariah auditor, (6) the institution's Shariah risk management process for identifying all possible Shariah non-compliance risks, (7) an internal Shariah research team, and (8) the issuance and dissemination of Shariah decisions to the relevant stakeholders.
An Islamic financial institution is required to set out the accountability and responsibility of every key functionary involved in the implementation of a shariah governance framework. In this regard, the Board of Directors is expected to not only have ultimate responsibility for the overall Shariah governance framework and the Shariah compliance of Islamic financial institutions, but also to perform diligent oversight of the Shariah governance framework's effective functioning [6].

The Shariah Committee will be held accountable for all of its Shariah-related decisions and opinions, and the Board will be required to trust the committee with all Shariah-related judgments and opinions pertaining to an Islamic financial institution's activity. In the institution's annual financial report, the Shariah Committee is expected to provide sufficient information on the state of compliance. At the same time, the Shariah Advisory Council and the Shariah Committee have entrusted management with the task of adhering to and implementing Shariah rulings and decisions. The management is responsible for creating and implementing a Shariahcompliant culture within the organisation.

\section{OBSERVATION}

The objectives of corporate governance of both conventional and Shariah systems seem similar in that both provide adequate disclosure, long-term corporate stability, and efficient and effective management[7]. However, as mentioned by Khalifa the distinctive characteristics of Islamic economics are that it is godly, ethical, humanly, moderate, and balanced.[8] There are two main institutions are involved in the Shariah governance framework, namely the Shariah board and the constituent of Shura's groups of participants, i.e. all the stakeholders. The Shariah board plays a crucial role in ensuring that all corporation activities are in line with the Shariah principles. The unique feature of the Shariah governance is that the shareholders also play a big role as active stakeholder in the process of decision making and drafting of policy framework, particularly by considering the interest of all direct and indirect stakeholders rather than merely minimising their profit.

Every stakeholder including the community also plays a role in providing a mutual cooperation with the company in order to protect the interest of all stakeholders. It can be implied therefore that having this kind of mutual participation and assistance among all the stakeholders will stimulate the social wellbeing function for social welfare in the society. All of these processes are centred towards fulfilling the ultimate objective of an Islamic corporate governance of complementing the private and social goals via upholding the principle of distributive justice[9].

\section{CONCLUSION}

It can be concluded that the framework for shariah corporations is different from that of a conventional 
corporation due to the issues of compliance with Shariah principles. Due to the absent of Shariah governance framework for Shariah Compliant corporation, therefore, it is a need to enact the new code by adopting the existing Shariah Governance Framework 2012 of BNM with certain modification.

It is important to have a Shariah corporate governance framework to specifically govern Shariah corporations. Having specific Shariah corporate governance would definitely boost the public confidence on shariah corporations. The Shariah corporate governance could enhance the role of the Shariah boards, board of directors, management, and the auditors of a shariah corporation. All of these organs of a shariah corporation shall execute their professional duties with the target of gratifying the rules imposed by God and the expectations of all stakeholders.

Definitely enacting a special code would promote accountability, transparency, disclosure, and clarity without prejudice. Such measures are much closer to the spirit of Islam and are the ways of creating and managing governance and social responsibility. The Shariah corporate governance code with the component of Shura and the obligation of CSR would certainly guide the company as Shariah Corporation in operating their business to be in accordance with the Islamic principles.

\section{REFERENCES}

[1] “About IFSB.”. https://www.ifsb.org/background.php

[2] Islamic Financial Services Board, Guiding Principles on Shari'ah Governance Systems for Institutions Offering Islamic Financial Services, no. December. 2009.

[3] S. A. S. Nawal Kasim, Sheila $\mathrm{Nu}$ NuHtay, "Comparative Analysis on AAOIFI, IFSB and BNM Shari ' ah Governance Faculty of Accountancy," Int. J. Bus. Soc. Sci., vol. 4, no. 15, pp. 220-227, 2013.

[4] R. Hassan, "Enhancing Shariah Compliance of Islamic Financial Institutions,” Bangi, 2018.

[5] “Act 701,” vol. 23, no. 8, pp. 1-99, 2020.

[6] S. Miskam, "Shariah Governance in Islamic Finance : The Effects of the Islamic Financial Services Act 2013," in Proceeding of the World Conference on Integration of Knowledge, WCIK 2013. 25-26 November 2013, Langkawi, Malaysia, 2013, no. November, pp. 455-463.

[7] M. M. Hafeez, "Analysis of Corporate Governance in Islamic and Western," Int. J. Business, Econ. Law, vol. 2, no. 3, pp. 98-103, 2013.

[8] A. M. Abu-Tapanjeh, "Corporate governance from the Islamic perspective: A comparative analysis with OECD principles," Crit. Perspect. Account., vol. 20, no. 5, pp. 556-567, 2009.
[9] Z. Hasan, "Corporate governance: Western and Islamic perspectives," Int. Rev. Bus. Res. Pap., vol. 5, no. 1, pp. 277-293, 2009. 